\title{
THE AUTHORSHIP OF THE "DE OCULO MORALI"
}

BY

\author{
R. R. JAMES \\ LONDON
}

THE De Oculo Morali, nowadays thought to be the work of John Peckham, Archbishop of Canterbury, was ascribed by Pits, Tanner and others to Robert Grosseteste, Bishop of Lincoln.

C. Trice Martin, in the preface to the third volume of Peckham's Register in the "Rolls Series," goes into the question of the author of this book at some length. He has examined 19 MSS. of the work, of which nine have no author's name at all ; in four, the Bishop of Lincoln's name is unhesitatingly given as the author; in one doubtfully (ut dicetur); in four this name is added by a later hand, and in one the treatise is said to be by Magister de Lunochia, which can be nothing but a misreading for Lincolnia. The earliest of the manuscripts are anonymous. No MSS. which Trice Martin has seen mentions Peckham's name in connexion with it, and therefore he knows nothing of the evidence before the Augsburg printer, who ascribed the authorship to Peckham, but imagines that he simply copied what he found on the MSS. he used, which may possibly still exist in some foreign library. He notes that though none of Peckham's other works show the same aptitude for story-telling; the style is much alike; the same pomposity and fondness for verbal jingles is evident and there is a manifest connexion between this work and the Perspectiva Communis. Many of the propositions in the De Oculo Morali are the same as those found in the Perspectiva Communis. But this point must not be emphasized unduly, for it is quite likely that Grosseteste was acquainted with the optical works of Al Hazen. In the De Oculo Morali various facts relating to the sense of sight and the phenomena of reflection and refraction are made pegs on which to hang moral tags and religious sermons. Thus : "The eye cannot see fog while surrounded by it, but can on leaving it, and thus a sinner cannot see the darkness of the $\sin$ in which he is enveloped till he has left it and is illuminated by the grace of God. If you push your eye out of place with your finger you see double. Thus prelates of the present day, through evil counsel, judge a priest to be worthy of two benefices where he ought to be contented with one. Thus tyrants thrust their servants into bishopricks without election. Thus when prelates object to promote unworthy clerks, their detractors distort their vision by perverse allusions to the example of holy men. Is it said that the clerk to be promoted is low born? Peter, the head of the Church, did not boast of his family. Is he ignorant, and 
never studied at Paris or elsewhere? Nor are the Apostles said to have gone to a University . . . . The larger apparent size of heavenly bodies when near the horizon than when in the zenith is compared to the increasing humility of heavenly-minded men as they rise in worldly dignity, and in treating of the diseases of the eye, a squint is compared to envy and inflammation to anger."

The moral tone which pervades the treatise is ascetic. The saint is praised who, on losing the sight of one eye, told his friends not to mourn, for of two enemies he had lost one. Chastity is extolled in the strongest terms; the author is obviously a man for he throws all the blame in this matter on the opposite sex.

The question of authorship of this book is an interesting point. Both Grosseteste and Peckham were of humble birth, both were outspoken champions of the Church and of morality. Of the two, I think that Peckham protested more against pluralities than Grosseteste. Both probably knew enough about optics to have written it, though it is generally held at the present time to be of a later date than that of Grosseteste.

\section{A CASE OF UVEO-PAROTID FEVER}

$$
\text { BY }
$$

H. KaItZ

LIVER POOL

UVEO-PAROTID fever is a rare clinical condition characterized by parotitis, uveitis, a mild fever, enlargement of the salivary glands and lymphatic nodes, and occasionally cerebro-spinal nerve palsies.

There is a diversity of opinion as to whether the tubercle bacillus is the aetiological agent. In one case reported in the literature the post-mortem examination revealed evidence of miliary tuberculosis.

\section{Case report.}

A female patient, aged 24 years, was admitted to St. Paul's Eye Hospital, Liverpool, on September 18, 1930, with the following history :

April, 1930. The patient felt "run down" and "out of sorts." She had lost weight and -had no appetite. These symptoms continued until May (1930), when her mother noticed that each side of the patient's face was swollen. The temperature was taken each morning and for several weeks remained in the region of $101^{\circ} \mathrm{F}$. This condition was regarded as " mumps." There was also enlargement of the cervical lymphatic nodes. 